\title{
Analysis of concrete structures deteriorated by alkali-aggregate reaction: case study
}

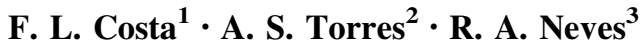

Received: 30 June 2016/Accepted: 1 November 2016/Published online: 11 November 2016

(C) Springer International Publishing Switzerland 2016

\begin{abstract}
This research aims to analyze the alkali-aggregate reaction with the case study of a waterfront structure pier, a reinforced concrete structure located in a marine environment in Brazil. In the present work is done a literature review on the subject of alkali-aggregate reaction, focusing on Brazilian standards, addressing the chemical mechanism, risk analysis and prevention of this pathological phenomenon. That said, petrographic analyses are also carried out for the characterization of the aggregates used in the structures of mooring dolphins of that pier. The results obtained in laboratory tests reveal the presence of characteristic minerals of the alkali-aggregate reaction in Dolphin C. However, the alkali-aggregate reaction has, as one of its features, the heterogeneous distribution along the affected structures, reason why it is very difficult to establish their degree of development and evolution stage. Therefore, it is not possible to define if the expansive process evidenced in Dolphin C will still be occurring over the years.
\end{abstract}

F. L. Costa

felmcosta@gmail.com

A. S. Torres

arielatorres@gmail.com

R. A. Neves

Rodrigo.neves@ifma.edu.br

1 UFRGS, Rua Oswaldo Aranha, 99, Centro, CEP: 90035-190 Porto Alegre, Rio Grande do Sul, Brazil

2 UFPel, Rua Gomes Carneiro, 1, Centro, CEP 96010-610 Porto Alegre, Rio Grande do Sul, Brazil

3 IFMA, Av. Marechal Castelo Branco, 789, São Francisco, CEP 65076-091 São Luís, Maranhão, Brazil
Keywords Concrete pathology $\cdot$ Alkali-aggregate reaction $\cdot$ Pier $\cdot$ Petrographic analyses

\section{Introduction}

The studied pier was built in the 1980s decade. Its structure was performed according to current legislation of the time, already setting a minimum lifetime of 50 years. However, after 30 years of use, it is necessary to maintain certain parts of the structure. That said, it was performed a survey of its physical state. Figure 1 shows the location of the structures that compose the pier.

The port area is considered one of the harshest environments for reinforced concrete structures since it has a high content of chlorides and sulfates. Furthermore, the pier is located in an area which has unique characteristics that enhance the effects of the aggressive marine environment. The region has high temperatures throughout the year, which accelerates chemical processes compared to cooler places. The tide variation may reach $8 \mathrm{~m}$ [1] depending on the season of the year, which causes a greater tidal zone and thus increases the surface of the affected structure. The significant variation of the water height results in a higher flow rate and, consequently, the water velocity under the pier is very high. This phenomenon, combined with a significant amount of debris from the rivers flowing nearby, results in an environment that favors the abrasion of seawater exposed structures. Also due to high water flow, there is a movement of clayey soil lying on the seabed, so that it increases the turbidity of the water, which practically precludes the execution of underwater inspections. Because of the structure's Property Management Policies (PMP), it is no possible to deliver further 


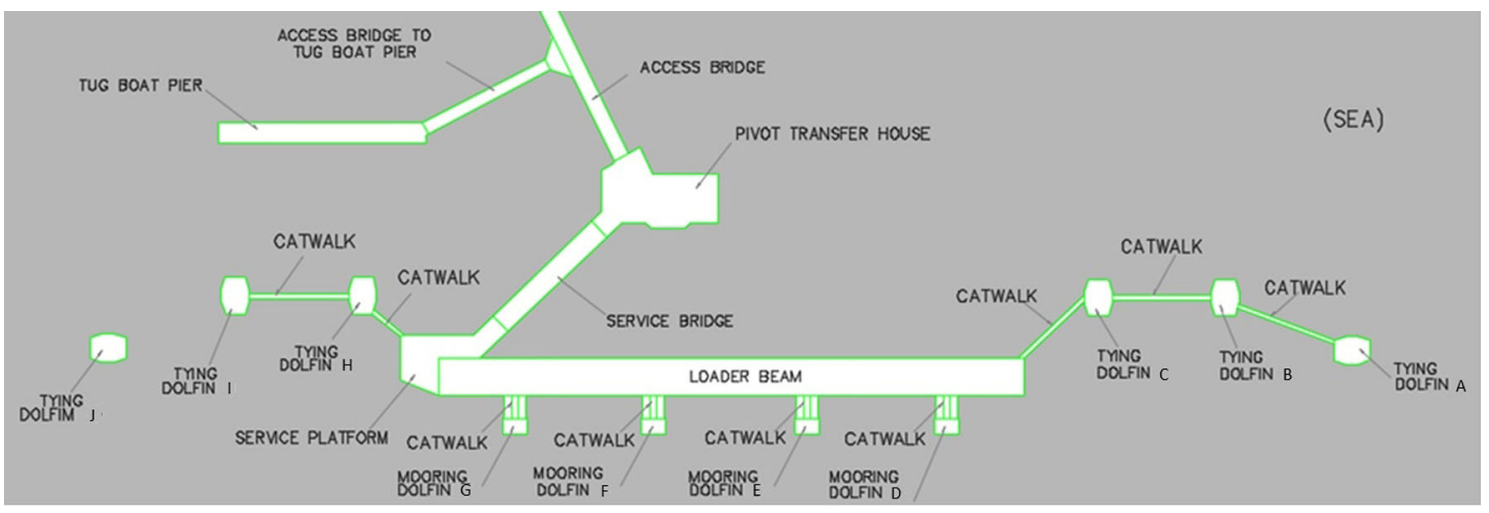

Fig. 1 Structures that compose the pier

geographic information onto this case study, but neither it is supposed to be part of the scope.

Based on these concepts, this paper proposes an analysis of alkali-aggregate reaction in the studied pier.

\section{Alkali-aggregate reaction}

The Brazilian standard NBR 15577-1 [2], defines the alkali-aggregate reaction (AAR) as:

A chemical reaction between certain constituents present in certain types of aggregates and alkali components that are dissolved in the solution of concrete pores. Its occurrence is conditional to the simultaneous presence of three factors: potentially reactive aggregate, moisture and alkalis.

The AAR is a highly expansive reaction, which generates internal stresses in the concrete and, therefore, cracking. Although hardly being the cause of collapse, the AAR allows the entry of aggressive agents that, in turn, may cause rapid deterioration of the structure.

It is widely known that the main evidence of this pathological manifestation are:

- Cracks in map shape;

- Whitish gel deposits in concrete pores;

- Edges surroundings of the aggregate grains with a characteristic coloration;

- Detachment of aggregate grains;

- Sharp drop of the flexural strength, with a possible drop in the compression strength and mainly in concrete modulus of elasticity, which may cause excessive deformation.

Examples of the effects of AAR on the concrete are shown in microscopic level, Fig. 2, and at a macroscopic level, Figs. 3, 4a, b.

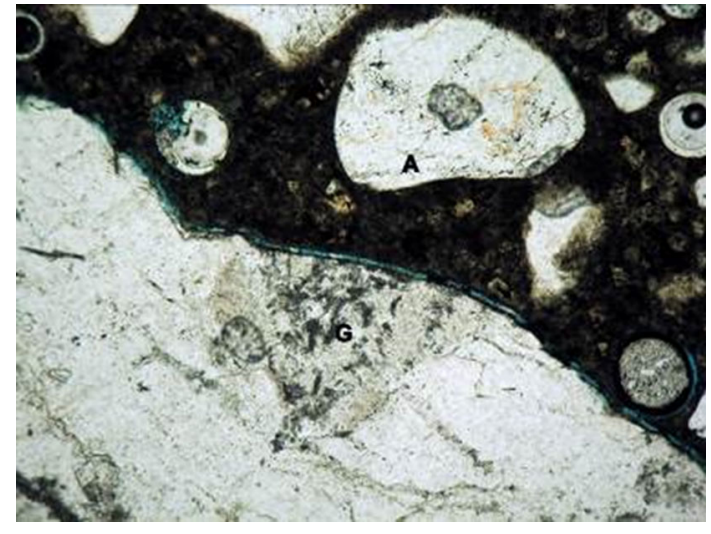

Fig. 2 Detail aspect of concrete-Dolphin $\mathrm{C}$ in which can be observed the gel reaction developed on the edge of the coarse aggregate. Transmitted light microscope-magnification $\times 50$

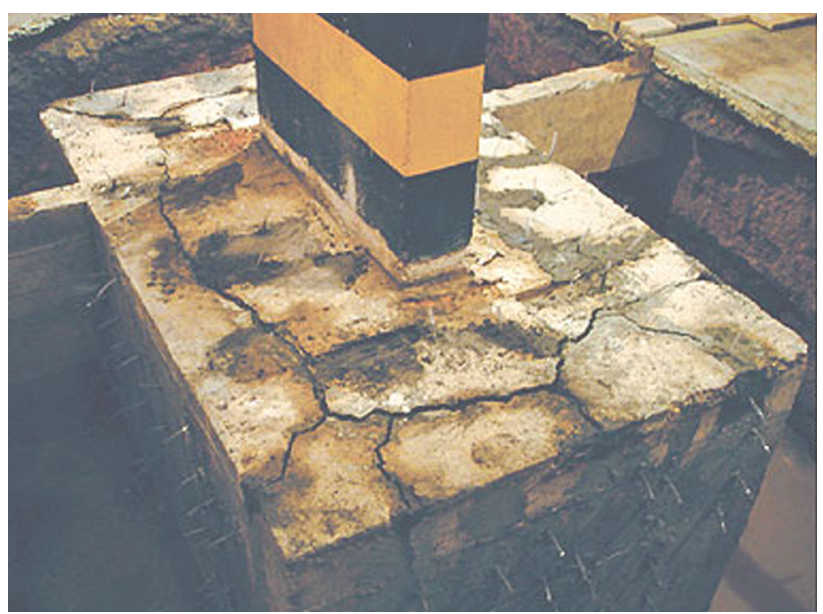

Fig. 3 Fissures in map format, resulting from the AAR on a foundation [5]

There are three types of AAR: alkali-silica reaction, alkali-silicate reaction and alkali-carbonate reaction. However, only the first reveals practical interest, since it 
Fig. 4 a Alkali-silica reaction in a pillar block [14]. b Alkalisilica reaction in concrete floors [14]
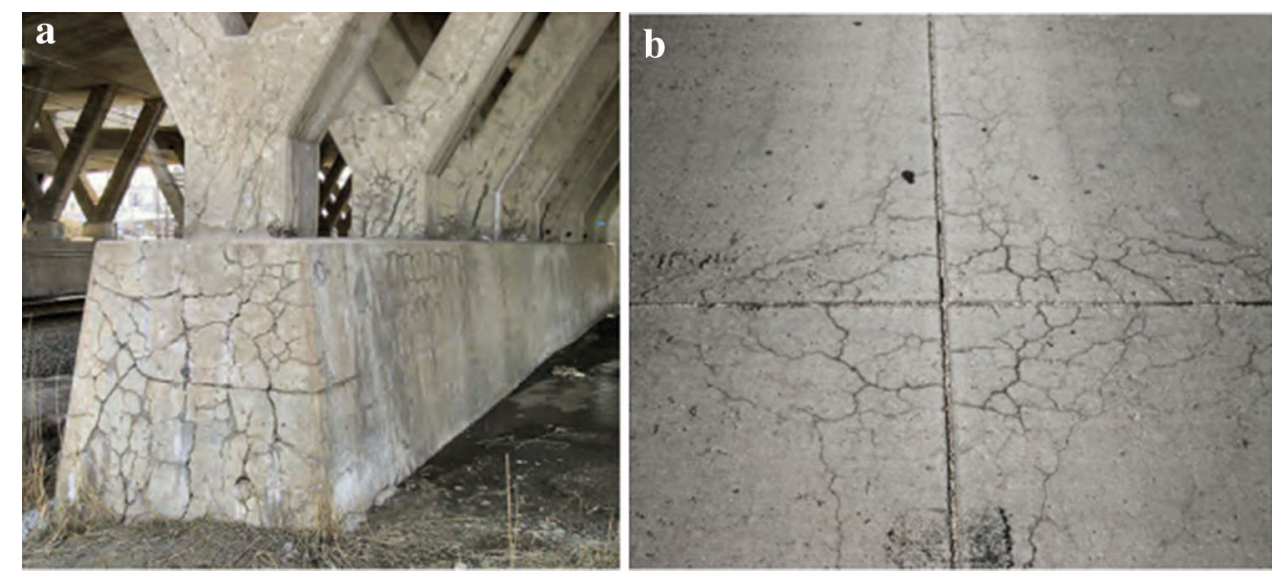

occurs with much higher frequency than the others. The NBR 15577-1 [3], defines them as:

\begin{abstract}
Alkali-silica reaction (ASR): type of alkali-aggregate reaction involving the reactive silica aggregates and alkalis in the presence of calcium hydroxide originated by the hydration of cement, forming an expansive gel. Examples of reactive silica: opal, tridymite, cristobalite, volcanic glass, among others. This is the kind of alkali-aggregate reaction with the fastest development.
\end{abstract}

\begin{abstract}
Alkali-silicate reaction: specific type of alkali-silica reaction involving alkalis and some types of silicates present in certain rocks. The most common reactive silicates are quartz tensioned by tectonic processes and minerals from the class of phyllosilicates present in slates, phyllites, schists, gneisses, granulites, quartzites, among others. Generally, this reaction is slower than the ASR.
\end{abstract}

Alkali-carbonate reaction: type of alkali-aggregate reaction involving alkalis and carbonatic rock aggregates. The best-known form of deterioration of the concrete is due to desdolomitization of the rock and consequent weakening of the paste-aggregate bond. No formation of an expansive gel, but compounds crystallized as brucita, alkaline carbonates, calcium carbonate and magnesium silicate. As the reaction regenerates the alkali hydroxides, the desdolomitization will continue until the dolomite has reacted completely or alkali source is exhausted.

\subsection{Alkali-aggregate mechanism}

The mechanism and some aspects of the reaction still present uncertainties. However, the basic model is evident. According to Ribeiro Cunha [4], the alkali-silica reaction occurs when the aggregate used in concrete has silica in its composition; this silica reacts with the alkali ions $\left(\mathrm{Na}^{+}\right.$and
$\left.\mathrm{K}^{+}\right)$and hydroxyl $\left(\mathrm{OH}^{-}\right)$, present in the interstitial solution of cement, and produces an alkali silicate gel. Calcium ions $\left(\mathrm{Ca}^{2+}\right)$, from the calcium hydroxide, get in touch with this alkali silicate gel originating calcium silicates, sodium and potassium gels. These gels absorb water molecules and expand, giving rise to the expansive phenomenon of AAR.

The alkalis content in the concrete plays a major role in the occurrence of ASR due to its influence in the concrete pore solution. An increased amount of $\mathrm{Na}^{+}$and $\mathrm{k}^{+}$lead to the dissolution of more hydroxyl ions $\left(\mathrm{OH}^{-}\right)$from $\mathrm{Ca}(\mathrm{OH})_{2}[1,2]$, which will increase the $\mathrm{pH}$ of the solution. The higher alkalinity will propitiate the dissolution of more reactive silica from the alkali-reactive aggregates.

The alkali ions can be originated from different sources, but mostly from cement [5]. Limestone and clays, the raw materials that compose the cement, can contain a certain amount of alkalis in their compositions. This is increasingly happening, due to the decrease in availability of good quality raw materials. Thus, due to the necessity of coprocessing of industrial residues, currently, they are being used as alternative sources of raw materials and/or combustible materials for cement production, alongside other possible effects, they often provide a certain amount of alkalis to the concrete constitution.

The AAR phenomenon reactions may occur very slowly, often after concrete hardening. According to Poole [6], the deterioration may occur within days, after years or even decades, until the cement alkali completely reacts with the aggregate. With an estimated average time from 5 to 12 years to develop.

The sodium and potassium ions are impurities from the cement, which must contain a maximum recommended concentration of these substances. As shown by the following equations [7]:

$\left(\% \mathrm{~N}_{2} \mathrm{O}+0.658 \% \mathrm{~K}_{2} \mathrm{O}\right) \leq 0.6 \%$ cement weight

Or

$\leq 3 \mathrm{~kg} / \mathrm{m}^{3}$ of concrete 
The alkali-aggregate reaction might be prevented by following these proportions, regardless the type of aggregate used.

Alternatively, lowering the $\mathrm{pH}$ of the pore solution beneath a critical level where the dissolution of alkali-reactive silica in the aggregates will be reduced or prevented, as concluded by Böhm and Baetzner [8]. However, lowering the $\mathrm{pH}$ might increase the susceptibility of other kinds of pathological phenomenon, such as carbonation and chloride ion attack.

Lindgård et al. [9] points that, internationally, various ways of controlling ASR are suggested (in addition to use of non-reactive aggregates): utilization of low-alkali cement, limiting the alkali content of the concrete, incorporation of supplementary cementitious materials (SCMs; e.g. silica fume, fly ash, ground granulated blastfurnace slag, metakaolin) or use of lithium salts. SCMs control expansion due to ASR by binding alkalis and limiting their availability for reaction with alkali-silica reactive aggregates [10].

The particle size of the silica also influences the reaction speed. According to Paulon [11], reactive aggregates with small dimensions may cause a deep and complete reaction before gel formation. Large amounts of fines, due to its large specific surface area, causes a rapid alkalis concentration reduction in such a way that the largest aggregates do not have the opportunity to undergo secondary reactions, avoiding the formation of the expansive gel.

Other determining factors for the occurrence of the AAR are the local temperature and humidity. The higher the temperature at the site, the faster the reaction may trigger and, hence, the expansive gel will manifest earlier. However, for the reaction to occur, the presence of water is necessary, which can be derived from direct contact with rain, seawater, and groundwater, in the case of foundations, or excess water in cases where the water/cement factor is higher than the necessary for hydration. Alternatively, a higher occurrence potential can be identified where the moisture is greater than $85 \%$, in a $20{ }^{\circ} \mathrm{C}$ scenario [5].

Given this, relevant factors for the alkali-aggregate reaction formation can be established, as follows:

- Potentially reactive aggregate;

- High humidity;

- cement alkalinity ( $\%$ content $\mathrm{N}_{2} \mathrm{O}+0.658 \% \mathrm{~K}_{2} \mathrm{O}$ );

- Temperature;

- Particle size of the material.

\subsection{Alkali-aggregate reaction analysis}

Several methods in literature seek to characterize an aggregate as its harmfulness compared to AAR. However, the Brazilian standard only mentions the petrographic analysis to characterize them by the expansion mitigation determination in mortar bars by the accelerated method, and by the expansion determination method in concrete prisms.

It is possible to identify, through petrography, the chemical composition of the mineral, as well as its texture. The operator visually analyzes the aggregate in order to define its geological characteristics and, thus, determine whether it has any reactive potential. However, for a more accurate diagnosis, the use of additional testing is often necessary. Pires [12] makes important observations on the peculiarities of the tests:

It is worth noting the subjective nature of this analysis. An experienced operator should perform it in order to obtain trusting results. It is also important to mention that the petrographic analysis classifies rocks (aggregate) only as to its reactive potential. The deleterious expansion analysis should be verified through tests that combine the aggregate with the cement, as for example, the prisms reactivity tests of concrete and mortar bars.

The Brazilian standard NBR 15577-3 [2], state the following about complementary techniques:

This part of ABNT NBR 15577 establishes the petrographic analysis procedures by optical microscopy. However, it may require complementary techniques such as selective staining of minerals, X-ray diffraction analysis (XRD), differential thermal analysis (DTA), infrared spectroscopy, scanning electron microscopy (SEM) and energy-dispersive X-ray analysis (EDX).

The expansion mitigation determination in mortar bars by accelerated method consists in immersing the mortar bars, containing the studied aggregate, in a sodium hydroxide solution $\mathrm{NaOH}$ with a concentration of $1 \mathrm{~N}$ at $80{ }^{\circ} \mathrm{C}$ for 14 days. If the result from this test indicates less than $0.19 \%$ expansion after 30 days, the aggregate is considered potentially safe for use in concrete.

If the obtained expansion is greater than or equal to $0.19 \%$ at 30 days, the aggregate is considered potentially reactive. In this case, the standard suggests the use of the expansion determination method in concrete prisms. The test requires a longer running time but offers greater accuracy in results. It involves exposing mortar prisms containing the studied aggregate in a saturated environment with water at $38{ }^{\circ} \mathrm{C}$ for 365 days. If the expansion is less than $0.04 \%$ the aggregate is considered potentially innocuous, if exceed $0.04 \%$ the aggregate is considered potentially reactive. 
Table 1 General characteristics of concrete

\begin{tabular}{|c|c|c|c|c|}
\hline Sample & Characteristics & $\begin{array}{l}\text { Sample } 01 \\
\text { Dolphin A }\end{array}$ & $\begin{array}{l}\text { Sample } 02 \\
\text { Dolphin B }\end{array}$ & $\begin{array}{l}\text { Sample } 03 \\
\text { Dolphin C }\end{array}$ \\
\hline \multirow[t]{8}{*}{ General aspects } & Mortar color & Grey greenish & Grey greenish & Grey greenish \\
\hline & Constituents distribution & Homogeneous & Homogeneous & Homogeneous \\
\hline & Constituents proportion & Mortar & Mortar & Mortar \\
\hline & $\begin{array}{l}\text { Mortar adherence to coarse } \\
\text { aggregate }\end{array}$ & Good & Good & Good \\
\hline & Macroscopic porosity & Shortly porous & Shortly porous & Shortly porous \\
\hline & Compacity & Compact & Compact & Compact \\
\hline & Consolidation & $\begin{array}{l}\text { Normal with many } \\
\text { exudation emptiness }\end{array}$ & $\begin{array}{l}\text { Normal with many } \\
\text { exudation emptiness }\end{array}$ & $\begin{array}{l}\text { Normal with many } \\
\text { exudation emptiness }\end{array}$ \\
\hline & Fracturing & Not observed & Not observed & Not observed \\
\hline \multirow[t]{3}{*}{$\begin{array}{l}\text { Aspects relative to } \\
\text { alkali-aggregate reaction }\end{array}$} & Reaction edges & Not observed & Rares and poorly defined & $\begin{array}{l}\text { Rares with gel deposits } \\
\text { inside the aggregates }\end{array}$ \\
\hline & Filled pores & Not observed & Not observed & Presents \\
\hline & Microcracks & Not observed & Not observed & Not observed \\
\hline
\end{tabular}

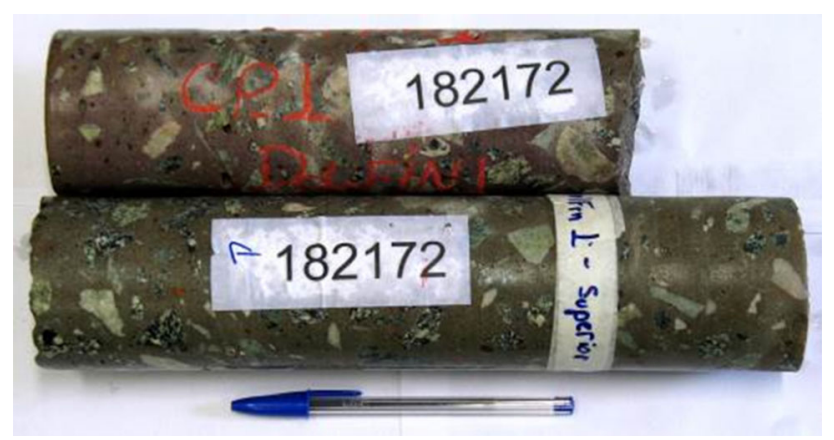

Fig. 5 General view of the concrete sample

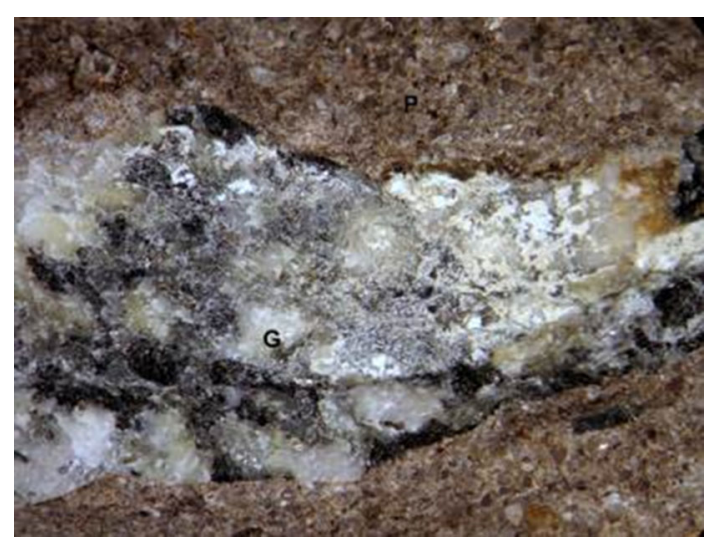

Fig. 6 Dolphin $\mathrm{C}$ sample in which there is a border of reaction around the coarse aggregate $(\mathrm{G})$ associated with the deposition of white material in its edges. Stereoscopic microscope $\times 12$ magnification

\section{Petrographic analysis: alkali-aggregate reaction}

Not all types of rocks are susceptible to expansion due alkali reactions inside concrete. However, the identification of those, which may be reactive, is a complex process. It is not possible to establish a general parameter, valid for all kinds of rocks, due to its implicit reactivity characteristics related to its geological history. A rock that is considered reactive in one region may be innocuous in another, therefore a classification must follow a regional or national experience [9]. RILEM AAR-1 [13], displays a list of potentially reactive rock types, referring to the countries where deleterious reactions were related to each rock.

\subsection{Petrographic analysis of the pier structure}

Specimens of the concrete structure were extracted in different parts of the pier, in regions where it was identified evidences of AAR, in order to assess their quality and durability, with emphasis on the observation of any possible expansive aggregate.

To identify the occurrence of AAR, the operator investigates the concrete samples, firstly in a visual way and after that, when necessary, with the help of complementary techniques. Aiming to verify the possible formation of AAR and other aggressive agents in the future, the tests can reveal a number of concrete characteristics such as porosity, compactness, the presence of cracks, among others. 
Table 2 General characteristics of coarse aggregate

\begin{tabular}{llllll}
\hline Type & Color & Form & Roundness & Dimension & \\
\cline { 4 - 5 } & & & & Variation range & Average size \\
\hline Crushed rock & Gray to pinkish gray & Equidimensional & Angular & $1.5-2 \mathrm{~cm}$ & $1.5 \mathrm{~cm}$ \\
\hline
\end{tabular}

Table 3 General characteristics of coarse aggregate

\begin{tabular}{lll}
\hline \multicolumn{2}{l}{ Physical and mechanical characterization } \\
\hline Brittle & Compactness & Tenacity (crack resistance) \\
\hline Not brittle & Compact & High \\
\hline
\end{tabular}

The petrographic examination should be carried out on the dominant sized fraction of the fine aggregate and the coarse aggregate, respectively. Examination of aggregate particles should be carried out by use of hand lens or stereoscopic microscope and in some samples by scratching for hardness or the use of diluted hydrochloric acid for identifying carbonate minerals. The aggregates can be divided in groups based on its grain form, color and texture, this grouping must include one group designated as innocuous aggregates and one group designated as potentially reactive (uncertain) aggregates. The NBR 15577-3 [2] establishes acceptable limits of reactive phases to classify an aggregate as potentially innocuous, the aggregate must constitute up to a maximum of $5 \%$ (deformed quartz), $3 \%$ (chalcedony), 1\% (tridymite or cristobalite),
$3 \%$ (volcanic glass) and $0.5 \%$ (opal). However, based on their experience, the operator can admit distinct boundaries.

For the pier, fine and coarse aggregates were collected through cylindrical specimens extracted in situ. The samples were analyzed in order to determine not only the aggregate characteristics but also the concrete applied.

\section{Results}

The main characteristics of the concrete Dolphins A, B and $\mathrm{C}$, identified macroscopically and with optical and stereoscopic microscopes, are summarized in Table 1.

The general aspects of the studied concrete, as evidenced in Table 1 , serve to determine their susceptibility to the aggressive agents present in the investigated environment. The samples showed that the concrete had a good density, good compactness and the absence of fracturing, which suggests a low permeability. However, it was observed the presence of alkali-aggregate reaction aspects in samples of Dolphin C.

Table 4 Petrographic characteristics summary of coarse aggregate

\begin{tabular}{|c|c|c|}
\hline Characteristics & Aggregate 1 & Aggregate 2 \\
\hline \multicolumn{3}{|l|}{ Mineralogy } \\
\hline Principal & Quartz, feldspars (microcline and plagioclase) & Quartz, feldspars (microcline and plagioclase) \\
\hline Subordinate & Amphibole, opaque, sericite epidote and chlorite & Biotite hornblende, opaque, sericite, chlorite and epidote \\
\hline Reactivity/deleterious & $\begin{array}{l}\text { Quartz with wavy extinction }\left(25^{\circ}-30^{\circ}\right) \\
\text { and altered feldspar }(20 \%)\end{array}$ & Microcrystalline quartz (10-20\%) \\
\hline Structure & Solid to slightly flaky & Flaky \\
\hline Texture & Granonematoblastic & Mylonitic \\
\hline Granulation & Inequigranular-medium to thick & Medium \\
\hline Alteration & Moderately changed with quite sericitizated feldspar & Weakly altered \\
\hline Aggregate deformation & $\begin{array}{l}\text { Deformed aggregate with foliation and } \\
\text { guidelines marked by amphibole orientation }\end{array}$ & $\begin{array}{l}\text { Deformed aggregate with masses of microgranular } \\
\text { crystals involving crystals }\end{array}$ \\
\hline Rock type & Metamorphic & Metamorphic \\
\hline Classification & Hornblende gneiss & Mylonite \\
\hline Potential reactivity & Potentially reactive & Potentially reactive \\
\hline
\end{tabular}

Table 5 Main characteristics of fine aggregate

\begin{tabular}{llllll}
\hline Roundness & Impregnations & Main mineralogy & Type/source & Change & Potential reactivity \\
\hline Rounded & Not observed & Quartz and rock fragments & Natural sand & \multirow{2}{*}{ Not changed } & Potentially innocuous \\
\hline
\end{tabular}




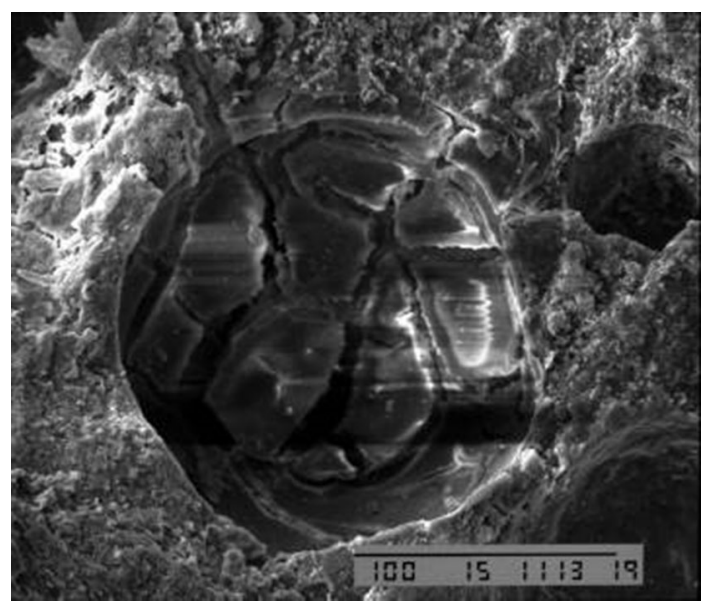

Fig. 7 Detail of a mortar pore containing the expansive gel resulting from alkali-aggregate reaction-scanning electron microscope$\times 1500$

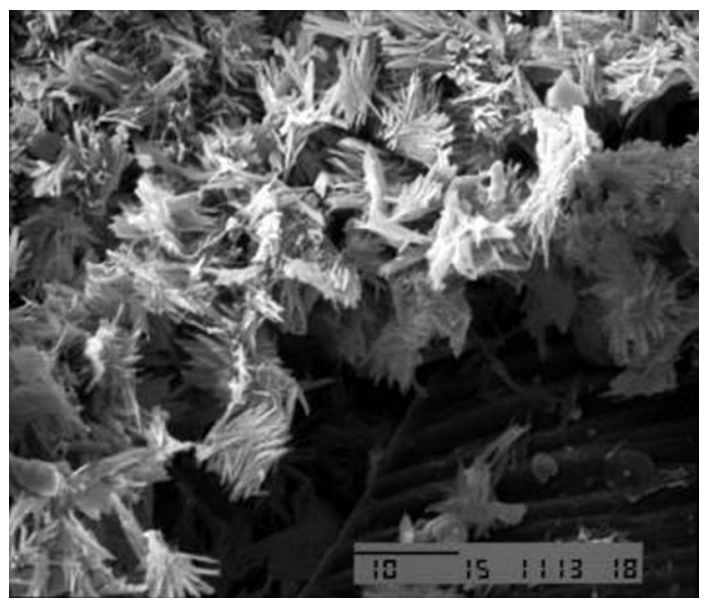

Fig. 8 Interface between the mortar and the coarse aggregate where lancet crystals resulting from alkali-aggregate reaction can be observed - scanning electron microscope $-\times 1500$

The concrete specimens displayed few voids and a regular distribution of aggregates through the mortar, indicating a well-executed consolidation, as evidenced in Fig. 5. The mortar had a greenish color, suggesting the use of cement with blast furnace slag addition. Fine aggregates were composed of quartz sands, with a spherical shape and some quartzite rock fragments. The coarse aggregates have an approximate granite composition and are constituted of angular fragments of a greenish rock.

The Dolphin C was the one which presented evidence of expansive phenomena related to alkali-aggregate reaction. Figure 6 shows the presence of white material deposited at the aggregate edges, characterizing possibly crystallized products of the reaction between concrete and alkali aggregate silica.

The examined concrete was mainly composed of crushed stone and natural sand aggregates. The analysis of aggregates characteristics serves to assist identifying the examined rock, to determine if it has elements that may provide the alkali-aggregate reaction. Tables 2, 3, 4 and 5 show the general and petrographic characteristics of coarse aggregates and fine aggregates.

The physico-mechanical characterization revealed that the aggregates are adequate for use in concrete. However, the mineralogical characterization reports that aggregate 1 has a significant amount of quartz with undulating extinction $\left(25^{\circ}-30^{\circ}\right)$ and altered feldspar, while Aggregate 2 has a high amount of microgranular quartz. Such aspects allow its classification as potentially reactive.

The petrographic analysis made possible the identification of potentially reactive aggregates in samples of Dolphin C. To confirm the reactivity, analyzes were performed with the aid of a scanning electron microscope, in the aggregate-mortar interface areas. The crystallized reaction products have mainly foliar and lancet habits, as shown in Figs. 7 and 8, respectively. They are typically grouped into "clumps" or masses that develop among, preferably, quartz or feldspar grains that constitute the coarse aggregates or overlay the mortar.

Samples of Dolphin C showed tenuous dark edges around some coarse aggregates, associated with the deposition of white material with a porcelain aspect on the concrete breaking surfaces. Occasionally, it is possible to observe the presence of expansive gel into the pores of the mortar.

\section{Conclusions}

Dolphin C samples showed typical features of an alkaliaggregate reaction from the alkali silicate type. However, the alkali-aggregate reaction has, as one of its features, a heterogeneous distribution along the affected structures. Reason why it is very difficult to establish their degree of development and evolution stage. Therefore, it is not possible to define if the expansive process evidenced in Dolphin $\mathrm{C}$ will still occur over the years.

Given the date of the pier execution, which is the 1980s decade, it is possible to affirm that the constructors followed the standards from that time, regarding the choice of aggregates. The mechanical characteristics of coarse aggregates were adequate, being only those related to its mineralogy that presented flaws. Such irregularities may be justified by the absence of a standard to instruct on the necessary precautions to prevent the emergence of the alkali-aggregate reaction.

At last, facing the presented results, it is possible to conclude that the studied pier does not present structural risks related to alkali-aggregate reaction. 


\section{References}

1. Diretoria de hidrografia e navegação. "Previsões de marés (máximas e mínimas diárias)." (Online). http://www.mar.mil.br/ $\mathrm{dhn} / \mathrm{chm} /$ box-previsao-mare/tabuas/index.htm/. Accessed on 19 Dec 2015

2. ASSOCIAÇÃO BRASILEIRA DE NORMAS TÉCNICAS (ABNT) (2008) "NBR 15577-3: Agregados - Reatividade alcaliagregado-Parte 3: Análise petrográfica para verificaçao da potencialidade reativa de agregado em presença de álcalis do concreto"

3. ASSOCIAÇÃO BRASILEIRA DE NORMAS TÉCNICAS (ABNT) (2008) "NBR 15577-1: Agregados-Reatividade álcaliagregado Parte 1: Guia para avaliação da reatividade potencial e medidas preventivas para uso de agregados em concreto"

4. Ribeiro DV, Cunha MPT (2014) Deterioração das estruturas de concreto armado. Corrosão Em Estruturas de Concreto Armado Teoria, Controle e Métodos de Análise. Elsevier, Rio de Janeiro, p 246

5. Figueirôa JP, Andrade T (2007) O ataque da reação álcali-agregado sobre as estruturas de concreto: a descoberta pioneira da ocorrência do problema em fundações de ponte e edifícios na região metropolitana do Recife, 1st ed. Editora Universitária UFPE

6. Poole A (1992) Introduction to alkali-aggregate reaction in concrete. The alkali-sílica reaction in concrete. Blackie and Son, Glasgow, pp 16-44

7. Mehta PK, Monteiro PJ (2014) Concrete: microstructures, properties, and materials. McGraw-Hill, USA
8. Böhm M, Baetzner S (2008) The effect of the alkalinity of the pore solution on ASR. In: 13th international conference on alkali-aggregate reactions in concrete, pp 501-510

9. Lindgård J, Andiç-Çakır Ö, Fernandes I, Rønning TF, Thomas MDA (2012) Alkali-silica reactions (ASR): literature review on parameters influencing laboratory performance testing. Cem Concr Res 42(2):223-243

10. Thomas M (2011) The effect of supplementary cementing materials on alkali-silica reaction: a review. Cem Concr Res 41(12):1224-1231

11. Paulon VA (1981) Reação Álcali-Agregado em Concreto. Escola politécnica da Universidade de São Paulo, São Paulo

12. Pires KO (2009) Investigação do potencial reativo álcali-agregado residual-um estudo de caso. Universidade Federal do Paraná, Curitiba

13. Sims I, Nixon P (2003) RILEM recommended test method AAR1: detection of potential alkali-reactivity of aggregates-petrographic method. Mater Struct 36(7):480-496

14. Thomas MDA, Fournier B, Folliard KJ, Resendez YA (2011) Alkali-silica reactivity field identification handbook, Washington, DC

15. Thomas MDA, Bleszynski RF (2000) The use of silica fume to control expansion due to alkali-aggregate reactivity in concrete-a review. Mater Sci Concr VI:377-433

16. Duchesne J, Bérubé M-A (2001) Long-term effectiveness of supplementary cementing materials against alkali-silica reaction. Cem Concr Res 31(7):1057-1063 